Pak. J. Agri., Agril. Engg., Vet. Sci., 2020, 36 (1): 68-77

ISSN: 1023-1072 (Print), ISSN: 2663-7863 (Online)

https://doi.org/10.47432/pjaaevs.2020.36.1.10

\title{
EFFECT OF RESTRICTED DIETS ON THE GROWTH AND MEAT COMPOSITION OF BROILERS
}

\author{
A. Memon ${ }^{1 *}$, G. M. Baloch, M. Khaskheli and T. A. Qureshi \\ ${ }^{*}$ Faculty of Animal Husbandry and Veterinary Sciences, \\ Sindh Agriculture University, Tandojam, Pakistan
}

\begin{abstract}
The trail related to the effect of restricted diets on the growth and meat composition of broilers was conducted at Department of Animal Nutrition, Sindh Agriculture University Tandojam, Pakistan. Fifty poultry feed ingredients were randomly selected and 30 least cost ingredients were purchased and analyzed for proximate analysis. After proximate analysis, three rations were formulated from 14 ingredients designated as Ration 1 (17\% crude proteins and 2900 Metabolizable energy). Ration 2 (21\% CP and $2800 \mathrm{ME})$ and Ration 3 (24\% CP and $2700 \mathrm{ME})$. After ration formulation, 45 day-old chicks were purchased and reared for each ration for six weeks. Chicks of each ration were further divided in three groups i-e A, B and C having 15 chicks in each. The chicks of each group were also divided in three replicates having 05 chicks. Group A was reared as control, group B was restricted to feed for 04 hours in brooding to rearing stage and group $C$ was restricted to feed for 08 hours daily in brooding to rearing stage. Results revealed the initial weight of a day-old broilers was non-significant $(P<0.05)$. Significantly higher $(P>0.05)$ feed consumption $(2218.74 \mathrm{~g})$ was observed in group $\mathrm{B}_{2}$, water consumption $7095.3 \mathrm{ml}$, and final body weight $1134.76 \mathrm{~g}$ in $\mathrm{B}_{3}$, weight gain $1086.61 \mathrm{~g}\left(\mathrm{~B}_{3}\right)$, carcass weight $716 \mathrm{~g}\left(\mathrm{~B}_{3}\right)$, dressing \% 63.10\% $\left(\mathrm{B}_{3}\right)$, FCR $1.853\left(\mathrm{~B}_{3}\right)$. Significant $(P>0.05)$ maximum meat moisture content $72.87 \%$ was noted in group $B_{3}$, meat protein $13.77 \%$ in $B_{3}$, fat $4.78 \%$ in $C_{1}$, and ash $1.85 \%$ in $B_{2}$. The better per bird profit gain of $\mathrm{Rs}$. 89.71 was recorded in $B_{2}$. It was concluded that the broilers can be restricted to their feed (containing 24\% CP and $2700 \mathrm{ME}$ ) for 04 hours daily in brooding to rearing period for better growth and meat composition but per bird profit margin was low due to high cost of production therefore, broilers can be reared economically on Ration 2 containing $21 \%$ CP and $2800 \mathrm{ME}$ and their feed can be restricted for 04 hours daily.
\end{abstract}

Keywords: broiler, feed restriction, growth, meat composition

\section{INTRODUCTION}

Agriculture economy in Pakistan plays pivotal role in the progress of allied sectors of economy by sharing 18.9 percent to the Gross Domestic Production (GDP) of the country, increasing foreign reserves and utilizing 42.3 percent labor force of the country. Livestock industry is the sub-sector of agriculture industry and it contributes 58.92 percent to total agriculture production with a share of 11.11 percent in GDP (GoP, 2018). Poultry being the most vibrant sector of livestock industry employs 1.5 million people directly or indirectly and is helping in curtailing the prices of beef and mutton. Moreover, commercial poultry production has the largest investment of 1168 billion rupees capital and is progressing at the rate of $10-12 \%$

Corresponding author: agsaad64@gmail.com per anum. It is producing 1440 million kilo grams chicken meat and producing 17500 million table eggs annually. In spite of its significant contribution in economy and self-sufficiency in meat production poultry is facing number of constrains such as sudden rise in the prices of feed grains, rise in the cost of feed supplements, increase in the transportation and electricity cost leading to the overall increase of $35 \%$ per bag price and heavy losses due to uncontrollable diseases caused by drug resistance and mutation in viral disease. For maximizing meat production broilers are being reared commercially at large scale which needs formulated high protein based feed. Broilers are selected for rapid weight gain and efficient feed utilization, they, have a great capacity to convert feed into tender meat by virtue of their genetic makeup. To fulfill the nutrient requirements of broilers, the farmers are using expensive 
commercial feed. The major cost in poultry production is feed that represents $70-75$ percent of total cost. Many farmers are unable to pay the current high rises in feed prices, therefore, searching strategies to cope with the rising feed cost. For this purpose, different feeding management programmes have been employed for reduction in feed cost but farmers are unable to achieve this target. Feed restriction is one of the alternative methods which can be defined as the total length of time the bird is without feed and includes the time the birds are in the house without feed (Buchanan, 2006). The prime aim of feed restriction is to stop wastage of feed and to restrict the amount of feed consumption. This method has been introduced in broiler farming for number of reasons such as to reduce the cost of feed consumption, to reduce broiler hypertension incidence prior to marketing age and to increase in net profit of the farmers in different climatic conditions. However, application of this methodology under our climatic conditions and feeding regimens is lacking. Keeping in view, the above facts the present study was designed. The main objective of this study was to provide relief to the poultry farmers by using various restricted feeding regimes to diets so that least cost ration and high production can be achieved. Very little work or research has been done so far in this field and this type of research has not been conducted in Pakistan in the past and will be beneficial for the poultry farmers of the country as well.

\section{MATERIALS AND METHODS}

Present investigation was conducted at the Department of Animal Nutrition, Faculty of Animal Husbandry and Veterinary Sciences, Sindh Agriculture University Tandojam, Pakistan. The following steps were taken:

\section{Selection of poultry feed ingredients}

Fifty poultry feed ingredients were randomly selected and used in ration formulation and out of them 30 ingredients were purchased and analyzed for proximate analyses to know the $\mathrm{CP}$ and energy level and market price and 14 chemically analyzed ingredients were used for least cost ration formulation.

Preparation of sample for proximate analysis Each poultry feed ingredients $(750 \mathrm{~g})$ was divided in three equal parts with labels and weighed. Samples were dried in hot-air oven over night and cooled in desiccator. After cooling, each sample was ground in grinder machine and stored for further analysis by the method of AOAC (2000). The following major nutrients of each ingredient were analyzed:

\section{Moisture content}

The moisture content formula is given below:

Moisture content $(\%)=\frac{W_{2}-W_{2}}{W_{2}-W_{1}} \times 100$

Where,

$W_{1}=$ Weight of empty dish

$\mathrm{W}_{2}=$ Weight of sample taken + Dish

$\mathrm{W}_{3}=$ Weight of dried sample + Dish

\section{Protein content}

The nitrogen \% was calculated using the following formula:

Nitrogen content $(\%)=\frac{1.4\left(V_{1}-V_{2}\right) X \text { Normality of } H C L}{\text { Weight of smapole taken } X \text { volume of diluted }} X 250$

Where,

$V_{1}=$ Titrated value of sample

$V_{2}=$ Titrated value of blank sample

\section{Fat content}

Finally, the weight of flask (with fat and empty) was taken and used in the following formula:

To compute the percent of fat in sample.

Fat content $(\%)=\frac{W_{2}-W_{1}}{W_{2}} \times 100$

Where,

$W_{1}=$ Weight of empty distillation flask

$\mathrm{W}_{2}=$ Weight of distillation flask + fat

$\mathrm{W}_{3}=$ Weight of sample taken

Fiber content

The fiber content formula is given below:

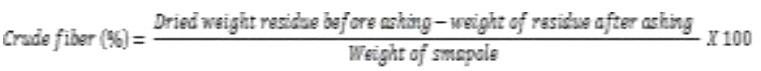

Ash content

The ash content was calculated by applying the following formula:

Total ash $(\%)=\frac{\text { Weight of ashed sample }}{\text { Weight of smapole taken }} X 100$

Metabolizable energy (ME)

ME was determined using bomb calorimeter.

\section{Amino acid concentration}

The value of Amino acids like Lysine, Methionine, Cystine and Tryptophan were derived from NRC (1994) Chart. 
Mineral contents (calcium and phosphorus)

The mineral contents were analyzed by the Method of AOAC (2000).

\section{Ration formulation}

After proximate analysis of 30 feed ingredients, 14 ingredients were used for three rations named as $R_{1}, R_{2}$ and $R_{3}$ on the basis of protein and energy level (Table 1 ).

\section{Proximate analysis of rations}

After ration formulation, three samples of each ration (starter and finisher) were analyzed according to the method of AOAC, (2000) as mentioned above. The following nutrients were available (Table 1).

\section{Preparation of experimental poultry house}

The shed was cleaned manually with tap water then washed with disinfectant thoroughly and left to dry for 24 hours. The brooding set-up was installed properly to maintain the required brooding temperature. $95^{\circ} \mathrm{C}$ and $90^{\circ} \mathrm{C}$ brooding temperature was maintained for first two weeks. The Semi-Intensive housing was adopted for rearing of birds. One sq. $\mathrm{ft}$ per bird space was allocated. The wooden dust was used as a litter material for 42 days. One-foot candle light was provided by using electric bulbs fit with ceiling at the height of 7 feet. Windows were also managed by wire net to prevent the entry of mosquitoes.

\section{Purchase and grouping of experimental chicks}

A total of 45-Day-old chicks were purchased and reared for each ration for six weeks. Chicks of each ration were further divided in three groups i-e A, B and C having 15 chicks each. The chicks of each group were also divided in three replicates having 05 chicks. Group A was reared as control, group B was restricted to feed for 04 hours daily in brooding to rearing stage and group $\mathrm{C}$ was restricted to feed for 08 hours daily in brooding to rearing stage. The feeder of each replicate was pulled out at restricted time.

\section{The following parameters were observed Weight of day-old broilers}

The weight of day-old broilers were measured by the help of electrical balance.

\section{Water intake}

The following formula was used to measure water intake on daily basis:

Water intake $=$ Water offered - Water consumed.

\section{Feed intake}

The following formula was used to measure feed intake on daily basis:

Feed intake $=$ Feed offered-Feed consumed .

\section{Feed wastage}

The feed wastage was measured with electric balance on daily basis.

\section{Total feed consumption}

The following formula was used to measure total feed consumption:

Total feed consumption $=$ Feed intake + Feed wastage.

\section{Final body weight}

The final body weight of broilers was measured by the help of electrical balance.

\section{Feed conversion ratio}

The following formula was used to measure feed conversion ratio:

FCR: $\frac{\text { Total feed consumption }}{\text { Total weight a gain }}$

\section{Weight gain}

The following formula was used to measure weight gain:

Weight gain= Final Body weight- Day-old weight.

\section{Carcass weight}

The following formula was used to measure carcass weight:

Carcass weight $=$ Final Body weight - (weight of visceral organs + feathers + toes + head=etc).

\section{Dressing \%}

The following formula was used to measure dressing \%:

$$
\text { Dressing }(\%)=\frac{\text { Carcass weight }}{\text { Final body weight }} \times 100
$$

\section{Bone meat ration}

The following formula was used to measure bone meat ratio:

Bone meat ratio $=\frac{\text { Weight of bones }}{\text { Weight of meat }}$

\section{Meat composition of broiler}

The meat composition of broiler will be checked by the protocol by the AOAC (2000) which includes measurement of moisture content, protein content, fat content, and ash content as described above.

\section{Economics of broilers}

It was calculated by subtracting total expenses from income and brought to per bird profit or loss. 
Profi $\mathrm{t}=$ Total Income- Total Expenses

\section{Data analysis}

The data thus collected was statistically analyzed using the statistical package (Gomes and Gomez, 2000). The data was analyzed for significant analysis on Two-WAY- ANOVA on Statistics 8.1 Version software.

\section{RESULTS}

Weight of day-old chick, water intake, total feed consumption, (feed intake + feed wastage) final body weight (FBW), feed conversion ratio (FCR) and weight gain of broilers was examined, and results are mentioned in Table 3 . Initial weight of day-old chicks was non-significant $(P>0.05)$. The maximum significant $(P<0.05)$ water consumption $7095.3 \mathrm{ml}$ was noted in group $B_{3}$ and minimum $5010.3 \mathrm{ml}$ was noted in group $\mathrm{C}_{1}$. The maximum significant $(P<0.05)$ total feed consumption including feed wastage $2187 \mathrm{~g}$ was noted in group $A_{1}$ and minimum $1810.3 \mathrm{~g}$ was noted in group $\mathrm{C}_{1}$. The maximum significant $(P<0.05)$ total final body weight $1134.76 \mathrm{~g}$ was noted in group $B_{3}$ and minimum $1810.3 \mathrm{~g}$ was noted in group $\mathrm{C}_{1}$.

The maximum non-significant $(P>0.05)$ feed conversion ratio 1.955 was noted in group $B_{2}$ and minimum 1.853 was noted in group $B_{3}$. The maximum significant $(P<0.05)$ weight gain $1086.61 \mathrm{~g}$ was noted in group $\mathrm{B}_{3}$ and minimum $849.62 \mathrm{~g}$ was noted in group $\mathrm{C}_{1}$. The results of carcass weight, dressing $\%$ and bone meat ratio are presented in Table 3 . The maximum significant $(P<0.05)$ carcass weight $7166 \mathrm{~g}$ was noted in group $B_{3}$ and minimum $468 \mathrm{~g}$ was noted in group $\mathrm{C}_{1}$. The maximum significant $(P<0.05)$ dressing percentile $63.10 \%$ was noted in group $\mathrm{B}_{3}$ and minimum $52.27 \%$ was noted in group $\mathrm{C}_{1}$. The maximum significant $(P<0.05)$ bone meat ration 1: 1.19 was noted in group $B_{3}$ and minimum 1:0.49 was noted in group $C_{1}$. The results of meat composition i-e moisture, protein, fat and ash content are presented in Table 4. The maximum significant $(P<0.05)$ meat moisture content $72.32 \%$ was noted in group $B_{3}$ and minimum $69.11 \%$ was noted in group $\mathrm{C}_{3}$. The maximum significant $(P<0.05)$ meat protein content $13.77 \%$ was noted in group $B_{3}$ and minimum $12.33 \%$ was noted in group $\mathrm{C}_{2}$. The maximum significant $(P<0.05)$ meat fat content $5.51 \%$ was noted in group $\mathrm{C}_{1}$ and minimum $2.10 \%$ was noted in group $B_{3}$. The maximum non-significant $(P>0.05)$ meat ash content $1.78 \%$ was noted in group $\mathrm{C}_{3}$ and minimum
$1.15 \%$ was noted in group $B_{3}$. The results on economics i-e expenses, income and per bird profit are presented in Table 5. The maximum per bird expenses of Rs.73.60 was noted in group $B_{3}$ and minimum $R s 50.60$ was noted in group $\mathrm{C}_{1}$. The maximum per bird income of Rs. 158.86 was noted in group $B_{3}$ and minimum Rs.125.34 was noted in group $C_{1}$. The maximum per bird profit of Rs.89.71 was noted in group $B_{2}$ and minimum Rs.73.93 was noted in group $\mathrm{C}_{3}$.

\section{DISCUSSION}

Day-old weight of broilers fed on restricted diets showed non-significantly $(P>0.05)$ results among all groups. These results are in agreement with findings of Gabel (2015) who reported that initial weight of chicks at the beginning of experiment did not differ significantly $(P>0.05)$ among all groups. The broilers restricted to feed for four hours daily fed on ration 3 drunk significant $(P<0.05)$ more water as compared to control group whereas less water drunken by the broilers restricted to feed for eight hours fed on Ration 1. These results may be due to the utilization of water in restriction period and due to the non-availability of feed at that time broilers were under rest and they well tolerated hunger and their vicious behavior was well controlled. Our results are in agreement with findings of Mench, (2002) who reported that birds kept under feed restriction methods showed a significant improved in water intake as compared to continuous fed birds. It is further argued by the Olayode et al. (2013) they reported that water intake of the birds significantly $(P<0.05)$ increased with increasing dietary protein.

The maximum significant $(P<0.05)$ feed was consumed by the broilers fed on Ration 1 and their feed restricted for 0 hours in brooding and rearing stage and minimum feed was consumed by the broilers fed on Ration 1 and their feed restricted for 8 hours in brooding and rearing stage whereas overall average of feed intake over three rations fed to broilers that Ration 1 consumed significantly $(P>0.05)$ comparatively less quantity of feed followed by Ration 2 and 3 , respectively. These results proved by Silval and Kalubovila, (2012) they reported when feed was offered after three hours of deprivation, birds consumed significantly $(P<0.01)$ higher amount of feed within first two hours, compared to the feed intake of ad libitum group during the same time period. 
Pak. J. Agri., Agril. Engg., Vet. Sci., 2020, 36 (1)

Table 1. Formulation of ration for broilers fed to broiler

\begin{tabular}{|c|c|c|c|c|c|c|c|}
\hline \multirow[t]{2}{*}{ Sr. No. } & \multirow[t]{2}{*}{ Ingredients (kg) } & \multicolumn{2}{|c|}{ Ration 1} & \multicolumn{2}{|c|}{ Ration 2} & \multicolumn{2}{|c|}{ Ration 3} \\
\hline & & Starter & Finisher & Starter & Finisher & Starter & Finisher \\
\hline 1 & Maize & 25.00 & 72.00 & 18.00 & 41.91 & 13.59 & 38.62 \\
\hline 2 & Rice Broken & 45.00 & & 43.41 & 30.00 & 38.00 & 22.00 \\
\hline 3 & Rice Polish & 3.82 & 6.92 & 4.22 & 3.29 & 4.00 & 3.00 \\
\hline 4 & Rice bran & 5.00 & 0.00 & - & - & - & \\
\hline 5 & Sorghum & & 3.30 & - & - & - & \\
\hline 6 & Sunflower meal & 2.00 & 2.00 & 5.00 & 3.00 & 5.00 & 4.00 \\
\hline 7 & Canola meal & 2.00 & 5.00 & 7.00 & 5.00 & 10.00 & 14.00 \\
\hline 8 & Guar meal & 2.50 & 2.50 & 6.00 & 4.00 & 5.50 & 3.00 \\
\hline 9 & Corn Gluten 30\% & 3.00 & 5.00 & 2.00 & 1.00 & 4.00 & \\
\hline 10 & Corn Gluten $60 \%$ & 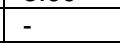 & - & 3.00 & 3.50 & 4.00 & 4.50 \\
\hline 11 & Fish meal & 11.00 & 3.00 & 9.00 & 8.00 & 13.50 & 10.50 \\
\hline 12 & Molasses & & - & 2.00 & - & - & 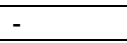 \\
\hline 13 & DCP & 0.40 & - & - & - & - & - \\
\hline 14 & Premix & 0.28 & 0.28 & 0.37 & 0.30 & 0.41 & 0.38 \\
\hline \multicolumn{2}{|l|}{ Total $(\mathrm{kg})$} & 100 & 100 & 100 & 100 & 100 & 100 \\
\hline \multicolumn{2}{|c|}{ Cost per kg ration (Rs) } & 29 & & 31 & & 35 & \\
\hline \multicolumn{8}{|c|}{ Chemical composition } \\
\hline \multicolumn{2}{|l|}{$\mathrm{ME}(\mathrm{Kcal})$} & 2925.26 & 3100.39 & 2817.39 & 3007.66 & 2754.24 & 2911.89 \\
\hline \multicolumn{2}{|l|}{ C P $(\%)$} & 16.92 & 14.01 & 20.41 & 18.32 & 24.35 & 22.48 \\
\hline \multicolumn{2}{|l|}{ Fat (\%) } & 3.32 & 4.69 & 3.23 & 3.54 & 3.72 & 3.80 \\
\hline \multicolumn{2}{|l|}{ Fiber (\%) } & 6.68 & 3.68 & 7.60 & 5.74 & 7.58 & 6.04 \\
\hline \multicolumn{2}{|l|}{ Ash (\%) } & 5.27 & 3.52 & 4.51 & 4.36 & 5.46 & 4.71 \\
\hline \multicolumn{2}{|l|}{ Moisture (\%) } & 9.93 & 11.05 & 9.97 & 10.68 & 9.57 & 10.26 \\
\hline \multicolumn{2}{|l|}{ Lysine (\%) } & 1.11 & 1.10 & 1.14 & 1.17 & 1.35 & 1.38 \\
\hline \multicolumn{2}{|l|}{ Methionine (\%) } & 0.41 & 0.34 & 0.46 & 0.44 & 0.55 & 0.53 \\
\hline \multicolumn{2}{|l|}{ Cystine (\%) } & 0.61 & 0.44 & 0.68 & 0.63 & 0.83 & 0.81 \\
\hline \multicolumn{2}{|l|}{$\begin{array}{l}\text { Tryptophan (\%) } \\
\end{array}$} & 0.16 & 0.12 & 0.20 & 0.17 & 0.23 & 0.21 \\
\hline \multirow{2}{*}{\multicolumn{2}{|c|}{ Calcium (\%) }} & 0.71 & 0.26 & 0.57 & 0.47 & 0.81 & 0.66 \\
\hline & Phosphorus (\%) & 0.0725 & 0.0072 & 0.002 & 0.004 & 0.0013 & 0.0038 \\
\hline
\end{tabular}

Table 2. Input and weight gain to broilers fed on restricted diets

\begin{tabular}{|c|c|c|c|c|c|c|c|c|}
\hline \multirow{2}{*}{$\begin{array}{l}\text { Group and } \\
\text { Ration }\end{array}$} & \multirow{2}{*}{$\begin{array}{l}\text { Weight } \\
\text { of day } \\
\text { old chick } \\
\text { (g) }\end{array}$} & \multirow{2}{*}{$\begin{array}{l}\text { Water } \\
\text { intake } \\
(\mathrm{ml})\end{array}$} & \multicolumn{3}{|c|}{ Feeding } & \multirow{2}{*}{$\begin{array}{l}\text { Final body } \\
\text { Weight (g) }\end{array}$} & \multirow[t]{2}{*}{ FCR } & \multirow{2}{*}{$\begin{array}{l}\text { Weight } \\
\text { gain } \\
\text { (g) }\end{array}$} \\
\hline & & & $\begin{array}{l}\text { Feed } \\
\text { intake } \\
(\mathrm{g})\end{array}$ & \begin{tabular}{|l} 
Feed \\
wastage \\
(g)
\end{tabular} & $\begin{array}{l}\text { feed } \\
\text { consumed } \\
\text { (g) }\end{array}$ & & & \\
\hline$A_{1}$ & $45.21^{\mathrm{a}}$ & $6022.7^{e}$ & 2135 & \begin{tabular}{|l|}
52 \\
52 \\
\end{tabular} & $2187^{9}$ & $1018.32^{9}$ & $1.955^{\mathrm{a}}$ & $973.11^{9}$ \\
\hline$A_{2}$ & $45.42^{a}$ & $6007.3^{\dagger}$ & 2123.7 & 45 & $2168.7^{d}$ & $1055.34^{\mathrm{d}}$ & $1.957^{\mathrm{a}}$ & $1009.92^{\mathrm{d}}$ \\
\hline$A_{3}$ & $45.37^{a}$ & $7073.3^{9}$ & $2097^{\prime \prime}$ & 35 & $2132.0^{\circ}$ & $1099.71^{\circ}$ & $1.956^{\mathrm{a}}$ & $1052.30^{\circ}$ \\
\hline $\mathrm{B}_{1}$ & $45.61^{\mathrm{a}}$ & $6039.3^{\mathrm{d}}$ & 2177.7 & 0 & $2177.7^{\dagger}$ & $1022.73^{t}$ & $1.955^{\mathrm{a}}$ & $977.10^{\dagger}$ \\
\hline $\mathrm{B}_{2}$ & $45.48^{a}$ & $7064.7^{\mathrm{C}}$ & 2169.7 & 0 & $2169.7^{a}$ & $1132.11^{b}$ & $1.959^{\mathrm{a}}$ & $1070^{b}$ \\
\hline $\mathrm{B}_{3}$ & $45.59^{\mathrm{a}}$ & $7095.3^{a}$ & 2100.7 & 0 & $2100.7^{c}$ & $1134.76^{\mathrm{a}}$ & $1.853^{\mathrm{a}}$ & $1086.61^{\mathrm{a}}$ \\
\hline $\mathrm{C}_{1}$ & $45.74^{\mathrm{a}}$ & $5010.3 \backslash$ & 1810.3 & 0 & $1810.3^{\prime}$ & $895.31^{\prime}$ & $1.948^{\mathrm{a}}$ & $849.62^{\prime}$ \\
\hline $\mathrm{C}_{2}$ & $45.62^{a}$ & $5028.7^{\mathrm{h}}$ & 2089.3 & 0 & $2089.3^{h}$ & $1010.34^{h}$ & $1.954^{\mathrm{a}}$ & $964.70^{\text {h }}$ \\
\hline $\mathrm{C}_{3}$ & $45.58^{a}$ & $5056.7^{9}$ & 2153.3 & 0 & $2153.3^{e}$ & $1033.33^{\mathrm{e}}$ & $1.955^{\mathrm{a}}$ & $987.73^{\mathrm{e}}$ \\
\hline LSD $(0.05)$ & & & & & & & & \\
\hline Group & 0.5922 & 0.5922 & & & 0.5922 & 0.5922 & 1.1769 & 0.5922 \\
\hline Ration & 0.5922 & 0.5922 & & & 0.5922 & 0.5922 & 1.1769 & 0.5922 \\
\hline Group ${ }^{*}$ Ration & $\begin{array}{l}1.0256 \\
\end{array}$ & $\begin{array}{l}1.0256 \\
\end{array}$ & & & 1.0256 & $\begin{array}{l}1.0256 \\
\end{array}$ & 2.0386 & 1.0256 \\
\hline$\underline{\mathrm{SE}+=}$ & & & & & & & & \\
\hline Group & 0.2793 & 0.2793 & & & 0.2793 & 0.2793 & 0.5552 & 0.2793 \\
\hline Ration & 0.2793 & 0.2793 & & & 0.2793 & 0.2793 & 0.5552 & 0.2793 \\
\hline Group* Ration & 0.4838 & 0.4838 & & & 0.4838 & 0.4838 & 0.96161 & 0.7838 \\
\hline P-Value $=$ & & & & & & & & \\
\hline Group & 0.2770 & 0.0000 & & & 0.0000 & 0.0000 & 0.9978 & 0.0000 \\
\hline Ration & & & & & 0.0000 & & 0.9976 & 0.0000 \\
\hline Group* Ration & 0.0162 & $0.0000 \backslash$ & & & 0.0000 & 0.0000 & 1.0000 & 0.0000 \\
\hline
\end{tabular}


Pak. J. Agri., Agril. Engg., Vet. Sci., 2020, 36 (1)

Table 3. Yield of broilers fed on restricted diets

\begin{tabular}{|c|c|c|c|}
\hline Group and Ration & Carcass weight (g) & Dressing \% & Bone: Meat Ratio \\
\hline$A_{1}$ & $577.00^{9}$ & $56.66^{\mathrm{d}}$ & $1: 0.72^{\mathrm{de}}$ \\
\hline $\mathrm{A}_{2}$ & $626.76^{\mathrm{d}}$ & $59.39^{b}$ & $1: 0.88^{\mathrm{cd}}$ \\
\hline$A_{3}$ & $640.00^{c}$ & $58.19^{c}$ & $1: 1.08^{\mathrm{ab}}$ \\
\hline $\mathrm{B}_{1}$ & $600.33^{\mathrm{e}}$ & $58.69^{c}$ & $1: 0.47^{\prime}$ \\
\hline $\mathrm{B}_{2}$ & $663.67^{b}$ & $58.62^{c}$ & $1: 0.91^{\mathrm{C}}$ \\
\hline $\mathrm{B}_{3}$ & $716.00^{\mathrm{a}}$ & $63.10^{\mathrm{a}}$ & $1: 1.19^{a}$ \\
\hline $\mathrm{C}_{1}$ & $468.00^{\prime}$ & $52.27^{t}$ & $1: 0.49^{\dagger}$ \\
\hline $\mathrm{C}_{2}$ & $553.00^{h}$ & $54.73^{\mathrm{e}}$ & $1: 0.69^{\mathrm{e}}$ \\
\hline $\mathrm{C}_{3}$ & $581.67^{\dagger}$ & $56.29^{d}$ & $1: 1.02^{\mathrm{bc}}$ \\
\hline $\operatorname{LSD}(0.05)=$ & 0.5922 & 0.5922 & 0.0947 \\
\hline Group & 0.5922 & 0.5922 & 0.0947 \\
\hline Ration & 1.0256 & 0.0256 & 0.1640 \\
\hline Group* Ration & & & \\
\hline$\underline{\mathrm{SE}+=}$ & 0.2793 & 0.2793 & 0.0447 \\
\hline Group & 0.2793 & 0.2793 & 0.0447 \\
\hline Ration & 0.4838 & 0.4838 & 0.0447 \\
\hline $\begin{array}{l}\text { Group Ration } \\
\text { P-Value }=\end{array}$ & & & \\
\hline Group & 0.0000 & 0.0000 & 0.0064 \\
\hline Ration & 0.0000 & 0.0000 & 0.0000 \\
\hline Group* Ration & 0.0000 & 0.0000 & 0.0367 \\
\hline
\end{tabular}

Table 4. Influence of restricted diets on meat composition of broilers

\begin{tabular}{|c|c|c|c|c|}
\hline Group and Ration & Moisture \% & Protein \% & Fat $\%$ & Ash \% \\
\hline$A_{1}$ & $70.88^{\text {cd }}$ & $11.32^{\mathrm{c}}$ & $3.14^{\mathrm{abc}}$ & $1.49^{\mathrm{a}}$ \\
\hline$A_{2}$ & $71.8^{\mathrm{bc}}$ & $12.11^{\mathrm{bc}}$ & $2.85^{\mathrm{abc}}$ & $1.68^{a}$ \\
\hline$A_{3}$ & $72.32^{a b l}$ & $12.41^{\mathrm{dbl}}$ & $2.52^{\mathrm{bc}}$ & $1.98^{\mathrm{a}}$ \\
\hline$B_{1}$ & $69.9^{\mathrm{de}}$ & $11.51^{\mathrm{bc}}$ & $3.75^{\mathrm{abc}}$ & $1.73^{\mathrm{a}}$ \\
\hline$B_{2}$ & $70.43^{\mathrm{del}}$ & $12.52^{\mathrm{a}}$ & $3.57^{\text {abe }}$ & $1.85^{\mathrm{a}}$ \\
\hline$B_{3}$ & $72.87^{\mathrm{al}}$ & $13.77^{\mathrm{a}}$ & $2.10^{\mathrm{C}}$ & $1.15^{\mathrm{a}}$ \\
\hline$C_{1}$ & $69.92^{\mathrm{de}}$ & $12.41^{b}$ & $4.51^{\mathrm{ab}}$ & $1.59^{\mathrm{a}}$ \\
\hline $\mathrm{C}_{2}$ & $69.78^{\mathrm{e}}$ & $12.33^{\mathrm{bc}}$ & $4.78^{\mathrm{a}}$ & $1.69^{\mathrm{a}}$ \\
\hline $\mathrm{C}_{3}$ & $69.11^{\mathrm{del}}$ & $12.43^{b}$ & $4.01^{\mathrm{abc}}$ & $1.78^{\mathrm{a}}$ \\
\hline $\begin{array}{l}\text { LSD }(0.05)= \\
\text { Group } \\
\text { Ration } \\
\text { Group }{ }^{*} \text { Ration }\end{array}$ & $\begin{array}{l}0.5922 \\
0.5922 \\
1.0256\end{array}$ & $\begin{array}{l}0.5922 \\
0.5922 \\
1.0256\end{array}$ & $\begin{array}{l}1.1942 \\
1.1942 \\
2.0685\end{array}$ & $\begin{array}{l}1.4593 \\
1.4593 \\
2.5275\end{array}$ \\
\hline $\begin{array}{l}\text { SE+= } \\
\text { Group } \\
\text { Ration } \\
\text { Group }{ }^{*} \text { Ration }\end{array}$ & $\begin{array}{l}0.2793 \\
0.2793 \\
0.3838\end{array}$ & $\begin{array}{l}0.2793 \\
0.2793 \\
0.3838\end{array}$ & $\begin{array}{l}0.5633 \\
0.5633 \\
0.9757 \\
\end{array}$ & $\begin{array}{l}0.6884 \\
0.6884 \\
1.1923 \\
\end{array}$ \\
\hline $\begin{array}{l}\text { P-Value }= \\
\text { Group } \\
\text { Ration } \\
\text { Group }^{*} \text { Ration }\end{array}$ & $\begin{array}{l}0.0000 \\
0.0000 \\
0.0385\end{array}$ & $\begin{array}{l}0.0098 \\
0.0023 \\
0.0350\end{array}$ & $\begin{array}{l}0.0276 \\
0.2193 \\
0.8812\end{array}$ & $\begin{array}{l}0.9774 \\
0.9788 \\
0.9661\end{array}$ \\
\hline
\end{tabular}

Table 5. Economics of broilers fed on restricted diets

\begin{tabular}{|l|l|l|l|}
\hline Group and Rations & Expenses (Rs) & Income (Rs) & Per broiler profit (Rs) \\
\hline$A_{1}$ & 57.75 & 142.56 & $84.81^{\mathrm{b}}$ \\
\hline $\mathrm{A}_{2}$ & 64.02 & 147.74 & $83.72^{\mathrm{c}}$ \\
\hline $\mathrm{A}_{3}$ & 75.32 & 153.96 & $78.63^{\mathrm{e}}$ \\
\hline $\mathrm{B}_{1}$ & 57.99 & 143.18 & $85.18^{\mathrm{b}}$ \\
\hline $\mathrm{B}_{2}$ & 68.78 & 158.50 & $89.71^{\mathrm{a}}$ \\
\hline $\mathrm{B}_{3}$ & 73.60 & 158.86 & $85.25^{\mathrm{b}}$ \\
\hline $\mathrm{C}_{1}$ & 50.60 & 125.34 & $74.74^{\mathrm{f}}$ \\
\hline $\mathrm{C}_{2}$ & 61.22 & 141.45 & $80.22^{\mathrm{d}}$ \\
\hline $\mathrm{C}_{3}$ & 70.73 & 144.66 & $73.93^{\mathrm{a}}$ \\
\hline
\end{tabular}


It is further evident from the report of Ghazanfari et al. (2010), that feed intake $(P<0.001)$ increased in broilers fed on lowenergy diets compared with those fed on highenergy diets during different restriction periods. Increasing levels of protein increased feed intake $(P<0.001)$. Only feed wasted showed by the broilers of control group. This is due to restriction of feed to other groups. The results of present study are in the line with the findings of Plavnik and Hurwitz (1989) they reported that feed wastage can be controlled in feed restriction method. The feed intake was observed significantly $(P>0.05)$ in rations, time for hours and time/ration.

The maximum significant $(P<0.05)$ final body weight was observed in the broilers restricted to feed on Ration 3 as compared to control group and minimum weight was noted in the broilers restricted to feed for eight hours fed on Ration 1 in brooding and rearing stage. This has been well documented by Türkyilmaz et al. (2006) who reported that feed withdrawal had significant effects on final body weight. The maximum significant $(P<0.05)$ feed conversion ratio was observed in the broilers restricted to feed on Ration 2 as compared to control group and minimum FCR was noted in the broilers restricted to feed for four hours on Ration 3 in brooding and rearing stage. The feed conversion ratio has shown significant response to the restriction of feed in broilers due to decrease in the rate passage of feed from the gastrointestinal rate as reported by Sibbald (1979) thus reducing the pumping of more feed into the tract and might have resulted in increased feed utilization of broilers. Similarly, these results are in accordance with the finding of Savory et al. (1996) they reported that different methods of feed restriction can be used to control growth rate within desired limitations. Oack and Erener (2005); Onderka and Hanson, (2006) and Urdaneta and Lesson, (2002) also reported that significantly feed conversion could be achieved by feed broilers fed on feed restriction. It is further documented by the Proud-foot et al. (1983) that the benefit of feed restriction are the monetary savings obtained by improved feed conversion. It is further argued by some workers that (Deaton, 1995; Lee and Lesson, 2001; Religious et al., 2001; Sahraei, 2012) that quantitative feed restriction improves feed conversion in broiler chickens. It is also reported by Osman and Toson (2011) that feed conversion ratios were in-significantly improved with increasing fasting time. It is further evident from the report of Ghazanfari et al. (2010), that feed intake $(P<0.001)$ and body FCR increased in broilers fed on low-energy diets compared to those fed on high-energy diets during different restriction periods. Increasing levels of protein increased FCR $(P<0.001)$ as compared with least level of protein. After calculation, the weight gain of broilers was observed significantly $(P>0.05)$ in rations, time and time/ration.

The maximum weight gain was observed in the broilers fed on Ration 3 and their feed restricted for 4 hours in brooding and rearing stage and minimum weight gain was noted in the broilers fed on Ration 1 and their feed restricted for 8 hours in brooding stage. The results of present study are in line with the findings of Olayode et al. (2013) who reported lowest weight gain for chickens on low protein diet compared with those fed the optimum $(P>0.05)$ and high protein diets $(P<0.05)$. It is further evident from report of Ghazanfari et al. (2010) that body weight gain increased in broilers fed on low-energy diets compared to those fed on high-energy diets during different restriction periods.

The maximum $(P<0.05)$ carcass weight was observed in the broilers fed on Ration 3 and their feed restricted for 4 hours in brooding and rearing stage and minimum carcass weight, was noted in the broilers fed on Ration 1 and their feed restricted for 8 hours in brooding and rearing stage. The results of present study are compareable with the findings of Silva and Kalubowila (2012) they reported that feed restriction strategies are proven to be effective in increasing carcass parameters of broiler chickens. Similarly, these results are not in agreement with the findings of Urdenata and Lesson (2002); Azarnik et al. (2010) who reported that carcass breast meat yield at 42 days was less in broilers subjected to mild feed restriction.

The maximum $(P<0.05)$ dressing percentile was observed in the broilers fed on Ration 3 and their feed restricted for 4 hours in brooding and rearing stage and minimum was noted in the broilers fed on Ration 1 and their feed restricted for 8 hours in brooding and rearing stage. These results of present study are in line with the findings of Osman and Toson (2011) who reported that feed restriction had insignificant effect on dressing percentage. The maximum $(P<0.05)$ bone meat ratio was observed in the broilers fed on Ration 3 and their feed restricted for 4 hours in brooding and rearing stage and 
minimum was noted in the broilers fed on Ration 1 and their feed restricted for 8 hours in brooding and rearing stage. The results of present study are in line with the findings of Karima and Fathy (2005) who reported that irrespective of protein level, increasing fiber level resulted in lowering meat: bone ratios in breast and wing also, within high level of protein, increasing fiber level led to decreasing meat: bone ratio in thigh and drumstick cuts. Meat: bone ratio in neck was significantly lower in chicks on high protein-high fiber diet than corresponding values in chicks on other diets.

The maximum moisture content in meat of broiler was observed in the broilers fed on Ration 1 and their feed restricted for four hours in brooding stage and minimum meat moisture content was noted in the broilers fed on Ration 3 and their feed restricted for eight hours in brooding to rearing stage. These results are in agreement with the findings of Berroeta (2007) who reported that feed restricted birds has significant effect on meat moisture than birds fed ad libitum. The maximum $(P<0.05)$ protein content in meat of broiler was observed in the broilers fed on Ration 3 and their feed restricted for four hours in brooding to rearing stage and minimum meat protein content was noted in the broilers fed on Ration 1 and their feed restricted for eight hours in brooding to rearing rearing stage. These results are in agreement with the findings of Berroeta (2007) who reported that feed restricted birds have significant effect on meat crude protein than birds fed ad libitum.

The better fat content in meat of broiler was observed in the broilers fed on Ration 3 and their feed restricted for four hours in brooding to rearing stage and poor meat fat content was noted in the broilers fed on Ration 1 and their feed restricted for eight hours in brooding to rearing stage. These results are in agreement with the findings of Berroeta (2007) who reported that feed restricted birds have significant effect on meat fat than birds fed ad libitum. The maximum meat ash content in meat of broiler was observed in the broilers fed on Ration 1 and their feed restricted for eight hours in brooding to rearing stage and minimum meat ash content was noted in the broilers fed on Ration 3 and their feed restricted for four hours in brooding to rearing stage. These results of present study are in line with the findings of Santoso (2001) who reported that ash in meat was significantly higher in the feed restricted birds. The results are in agreement with the findings of Omosebi et al. (2014) they reported that crude protein increased and fat contents was lowest at feed restriction. On the contrary Butzen et al. (2013) reported that meat quality standards are not affected by the feed restriction programs. It is further stated by the Ziphozihle (2014) who reported that feed restriction can be suitable for the meat composition of broiler chickens. This might be due to fact that 04 hours feed restriction caused accumulated fat in the tissues to decrease when in hunger.

The expenses including day-old chicks, feed, birds and miscellaneous costs of broiler was observed minimum incurred by the broilers fed on Ration 1 and their feed restricted for eight hours in brooding stage and maximum incurred by the broilers fed on Ration 3 and their feed restricted for zero hours in brooding to rearing stage. These results are may be due to high cost of feed ingredients. The maximum income was received by the broilers fed on Ration 3 and their feed restricted for four hours in brooding stage and minimum received by the broilers fed on Ration 1 and their feed restricted for eight hours in brooding to rearing stage. These results are may be due to maximum better final body weight. The maximum profit was earned by the broilers fed on Ration 2 and their feed restricted for 4 hours in brooding stage and minimum earned by the broilers fed on ration 3 and their feed restricted for 8 hours in brooding to rearing stage. These results may be due to low expenses and high income. These results are in agreement with the findings of Makinde (2012), who also reported that duration and timing of feed restriction can reduce cost in broiler meat production without seriously affecting performance or economics of production depending on the restriction program applied and our results are also in agreement with the finding of Mehmood (2012) who observed that feed restriction programs can be profitable in broiler chicken production. The broilers of either sex can be fed on Ration 3 and their feed can be restricted for four hours daily in brooding to rearing stage but as protein level increases, the ration cost is increased and ultimately profit margin of ration 3 was low due to high cost of feed and low profit margin. Therefore, broilers can be reared economically on least cost ration 2.

\section{CONCLUSION}

It was concluded that the broilers can be restricted their feed (containing 24\% CP and $2700 \mathrm{ME}$ ) for 04 hours daily in brooding to rearing period for better growth and meat 
composition but per bird profit margin was low due to high cost of production, therefore, broilers can be reared economically on Ration 2 containing 21\% CP and $2800 \mathrm{ME}$ and their feed can be restricted for 04 hours daily. It is, further concluded that broilers feed can be restricted for four hours daily and beyond this cost and time, broilers performance can be uneconomical in our local conditions.

\section{AUTHOR'S CONTRIBUTION}
A. Memon: Conducted research
G. M. Baloch: Supervised
M. Khaskheli: Co-Supervised
T. A. Qureshi: Co-Supervised

\section{REFERENCES}

Azarnik, A., M. Bojarpour, M. Eslami, M. R. Ghorbani and K. Mirzadeh. 2010. The effect of different levels of diet protein on broilers performance in ad libitum and feed restriction methods. Journal of Animal and Veterinary Advances 9 (3): 631-634.

Anonymous, 2018-19. Poultry feed ingredient definition. https://www.google.com/search. [Assessed on March 08, 2019].

AOAC, 2000. Official methods of Analysis (15 th Ed.). Association of Official Analytical Chemists. Washington.D.C.

Butzen, F. M., A. M. L. Ribeiro, M. M. Vieira, A. M. Kessler, J. C. Dadalt and M. P. Della. 2013. Early feed restriction in broilers. IPerformance, body fraction weights, and meat quality. Journal of Applied Poultry Research, 22 (2): 251-259.

Ghazanfari, S., H. Karmanshahi, M. R. Nassiri, A. Golian, A. R. H. Mousavi and A. Salehi. 2010. Effect of feed restriction and different protein and energy levels of the diets on growth performance and growth hormone in broiler chicken. Journal of Biology Sciences, 10 (1): 25-30.

Gomes, K. A. and A. A. Gomes. 2000. Statistics for Agriculture Research (2 ${ }^{\text {nd }}$ Ed.), John Wiley and Sons. New York.

GoP, 2018. Agriculture. Economic Survey of Pakistan, Islamabad. pp-280.

Karima, A. S. and F. A. Elazeem. 2005. Effects of breed, sex and diet and their interactions on carcass composition and tissue weight distribution of broiler chickens. Archives. Tierz, Dummerstorf, 48 (6): 612-626.

Lee, K. H. and S. Leeson. 2001. Performance of broilers fed limited quantities of feed or nutrients during seven to fourteen days of age. Poultry Science, 80 (4): 446-454.

Mahmood, S. 2012. Feed restriction in broiler chickens production: A Global Veterinaria. 8 (5): 449-458,

Makinde, O. 2012. Urbanization, housing and environment: megacities of Africa. International Journal of Development and Sustainability, 1 (3): 976-993.

Mench, J. A. 1999. Broiler breeders: feed restriction and welfare. A1 Department of Animal Science, One Shields Avenue, University of California, Davis, CA, 95616, USA.

NRC, 1994. Nutrient Requirements for Poultry. 9th Edn. National Academy Press; Washington DC, USA.

Ocak, N. and G. Erener. 2005. The effect of restricted feeding and form on growth, carcass characteristics and days to first egg of Japanese Quail (Countrix japonica). Asian-Australasian Journal of Animal Sciences, 18 (10):1479-1484.

Olayode R. Folorunso, Aanuoluwapo A. Adesua and Gbenga E. Onibi.2013. Response of broiler chickens to diets of varying protein contents under ad libitum and skip-a-day feeding regimes. African Journal of Agriculture, 9 (1): 113-118.

Omosebi, D. J., O. A. Adeyemi, M. O. Sogunle. 2014. Effects of duration and level feed restriction on performance and meat quality of broiler chickens. Archives.ootec. 63 (244): 611-621.

Onderka, D. K. and J. A. Hanson. 2006. Growth performance of broiler chicks after severe early feed restriction. http://www.estvet. com/feed_restrict.htm.

Pan, J. Q., X. Tan, J. C. Li, W. D. Sun and X. L. Wang. 2005. Effects of early feed restriction and cold temperature on lipid peroxidation, pulmonary vascular remodelling and ascite morbidity in broilers under normal and cold temperature. British Poultry Science, 46 (3): 374-81.

Plavnik, I., E. Wax, D. Sklan and S. Hurwitz. 1997. The response of broiler chickens and turkey poults to steam-pelleted diets supplemented with fat or carbohydrates. Poultry Science, 76 (7): 1006-1013.

Proudfoot, F. G., H. W. Hulan and K. B. McRae. 1983. The effect of feed denial in starter diets on the performance of broiler chickens. Poultry Science, 62 (9):1915-7.

Sahraei, M. and M. H. Hadloo. 2012. Effect of physical feed restriction in finisher period on 
carcass traits and broiler chickens performance. Global Veterinaria, 9 (2): 201-204.

Santoso, U. 2001. Effect of early feed restriction on growth, fat accumulation and meat composition in unsexed broiler chickens. Asian-Australasian Journal of Animal Sciences, 14 (11): 1585-1591.

Savory, C., P. Hocking, J. Mann and M. Maxwell. 1996. Is broiler breeder welfare improved by using qualitative rather than quantitative food restriction to limit growth rate? Animal Welfare, 5 (2): 105-127.

Sibbald, I. R. 1997. The effect of level of feed intake on metabolizable energy values measured with adult roosters. Poultry Science, 54 (6):1990-1997.

Silva, P. H. G. J. and A. Kalubowila. 2012. Influence of feed withdrawal for three hour time period on growth performance and carcass parameters later stage of male broiler chickens. Iranian Journal of Applied Animal Science, 2 (2): 191-197.

Swain, B. K. 2016. Low cost feed formulation for rural poultry production. Empowering Farm women through livestock and poultry intervention, Publisher: ICAR-Central Institute for Women in Agriculture, pp-186194.

Türkyilmaz. M. K., A. Nazligül, S. Türkyilmaz and E. Fidan. 2006. Effects of different feed withdrawals on performance and fecal contamination of carcass in broiler chickens. International Poultry Science, 5 (10): 975978.

Ziphozihle, G. 2014. The effect of feed restriction duration on growth performance, physico-chemical characteristics and fatty acid composition of meat from broilers. M.Sc. Thesis Department of Livestock and Pasture Science. Faculty of Science and Agriculture, Alice, South Africa, pp.114.

(Received: July 30, 2019; Accepted: June 03, 2020) 